\title{
Credit Risk and Banks' Profitability in Malaysia
}

\author{
Norlina Kadri, Bakri Abdul Karim and Kelvin Lee Yong Ming \\ Faculty of Economics and Business, Universiti Malaysia Sarawak (UNIMAS), Malaysia
}

\begin{abstract}
This paper examines the relationship between credit risk and profitability of Malaysian local commercial banks which consist of eight banks they are Maybank, CIMB Bank, Hong Leong Bank, Public Bank, RHB Bank, AmBank, Alliance Bank, and Affin Bank. For the purpose of analysis this study covers a period of eight years from 2005 to 2012. The empirical tests employed in this study are Pooled Ordinary Least Square (OLS) and Panel regression. Based on the findings of this study its shows that the nonperforming loan to total loan ratio (NPL/LA) and the ratio of loan loss provision to total loan (LLP/LA) have a negative effect on profitability meanwhile the total loan to total deposit ratio (LA/TD) found to have a positive effect on the return on asset (ROA). Overall the results of this study concluded that to some degree, Malaysia's commercial banks have a very good credit risk policy.
\end{abstract}

Keywords: Credit risk; Profitability; Banks, Malaysia

\section{INTRODUCTION}

As a monetary institution that is crucial to the economic development by providing various financial services to the public such indicators as bank's performance will always attract the interest of the consumer public (Kolapo, Ayeni \& Oke, 2012). In fact, banks play a crucial role in the operation of most economies (Demirguc-Kunt and Huizinga, 1998). A bank exists not only to accept deposits but also to grant credit facilities (loan), inevitably exposing this institution to credit risk (Kolapo et al. 2012). Credit risk or default risk is one of the key indicators to banks and economy of a country. Having mention this, there are many factors that can influence the credit risk. The most common method used by researchers to measure credit risk according to Chen \& Pan (2012) was calculating the financial ratios and nonperforming loan to total loans. Non-performing loan to total loan ratio can be calculated by dividing nonperforming loan with total loan.

It is crucial for a financial institution to maintain its credit risk at a lower level and be able to manage its credit risk in order to avoid the damaging effect of credit risk to the financial institution profitability. Lesson learned from the collapsed of Lehman Brother due to the 2008 mortgage crisis caused by an extremely high level of default risk in mortgage loan or Mortgage Backed Securities (MBS).

There are rather limited studies examining the relationship between credit risk and banks' profitability particularly in emerging markets. Studies by-Cerci, Kandir, and Onal (1997), Aduda and Gitonga (2011), Kolapo et al. (2012), Nawaz et al. (2012), Boahene et al(2012); Poudel (2012), Syafri (2012), Sufian and Noor (2012), Berríos (2013), Abbas et al (2014) and Abiola and Olausi (2014) are worth highlighting. From the findings of studies, their studies indicated mixed results. For example, Kolapo et al. (2012) and Nawaz et al. (2012) Findings indicated that the non-performing loan to loan \& advances (NPL/LA) and loan loss provision to total loan Have a negative effect on profitability (ROA) of banks in Nigeria. In addition, Aduda and Gitonga (2011) also find a negative relationship between credit risk management and profitability in commercial banks in Kenya. On the contrary, Boahene, Dasah and Agyei (2012) Findings showed that the credit risk have a positive and significant relationship with the profitability performance (ROE) of the banks. The results are also consistent with Abiola and Olausi (2014) study that discovered the credit risk positively affected the profitability (ROA) of the commercial 
bank in Nigeria. A similar finding was indicated by Sufian and Noor (2012) that found a positive relationship in banks in India. Interestingly, Cerci, Kandir, and Onal (1997) findings indicated no significant relationship between loan credit risk and ROA. To sum up studies revealed that Return on asset (ROA) is positively affected by total deposits to total loans ratio and non-interest income to total assets ratio and also negatively affected by non-interest expenses to net income ratio.

Having mentioned this, we still find inconclusive relationship between credit risk and profitability of bank from these previous findings thus, making this issue still open for further investigation. Therefore, this paper attempts to further shed some light on this issue using Malaysia as a case study.

The next section of this paper presents details on the performance of Malaysian's commercial banks. Section three discusses data and methodology followed by empirical findings section and finally a conclusion.

\section{MALAYSIAN COMMERCIAL BANKS PERFORMANCE}

\section{Non-Performing Loans to Total Gross Loan Ratio (\%) in Malaysia}

Figure 1 shows a comparative bank's non-performing loans to total loan ratio in Malaysia and the United States (US) that is measured in the percentage from the period of year between 2005 and 2012. Compared to the US, the non-performing loans to total loan ratio in Malaysia indicated a downward trend from 9.6\% in 2005 to reach a low of $2.2 \%$ points in 2012 .

\section{Figure 1: Bank's Non-Performing Loans to Total Gross Loan Ratio (\%) in Malaysia and United States for the Year of 2005 until 2012.}

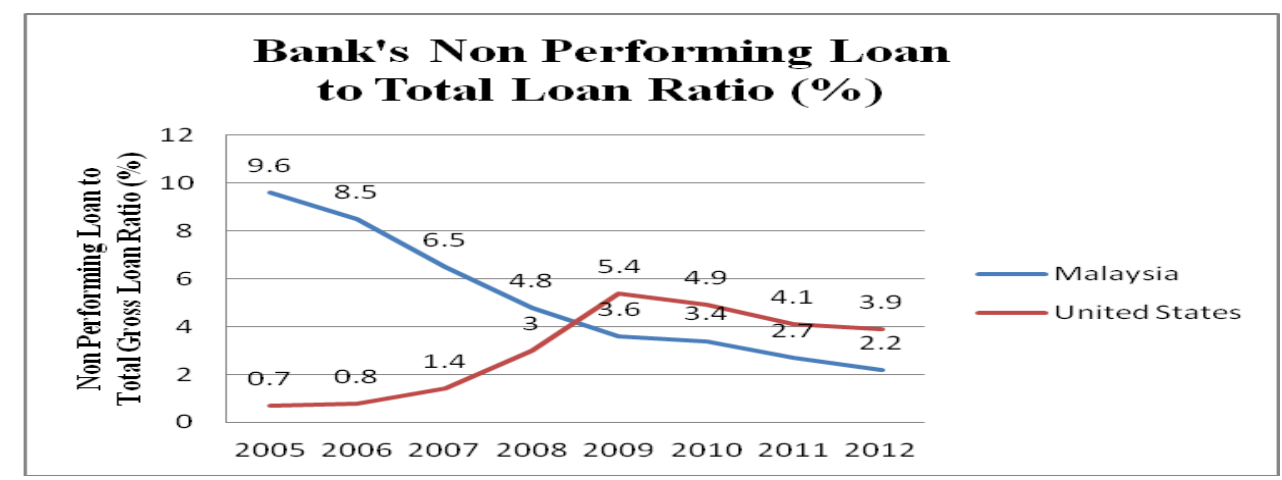

Sources: The World Bank Official Website

\section{Average Total Asset and Total Loan of Malaysian Local Commercial Banks}

Figure 2 and Figure 3 indicates the average total asset and average loan and advances of Malaysian local commercial banks between 2005 and 2012. Both the average asset and average loan and advances show a consistent upward sloping trend between 2005 and 2012. From figure 2, also demonstrate a consistent increased in the size of total asset of the Malaysian's local commercial banks. In addition, Figure 3 shows that the loan given out or approved by Malaysian local commercial banks also increased steadily between 2005 and 2012. 
Figure 2: Average Total Assets of Malaysia Local Commercial Banks from 2005 to 2012

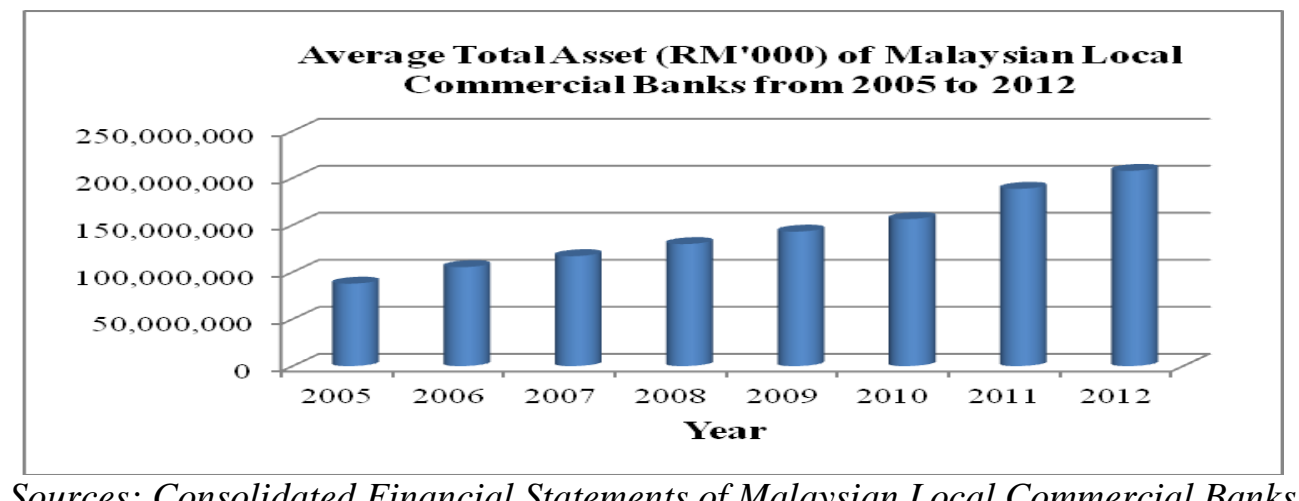

Sources: Consolidated Financial Statements of Malaysian Local Commercial Banks

Figure 3: Average Total Loan \& Advances of Malaysian Local Commercial Banks from 2005 to 2012

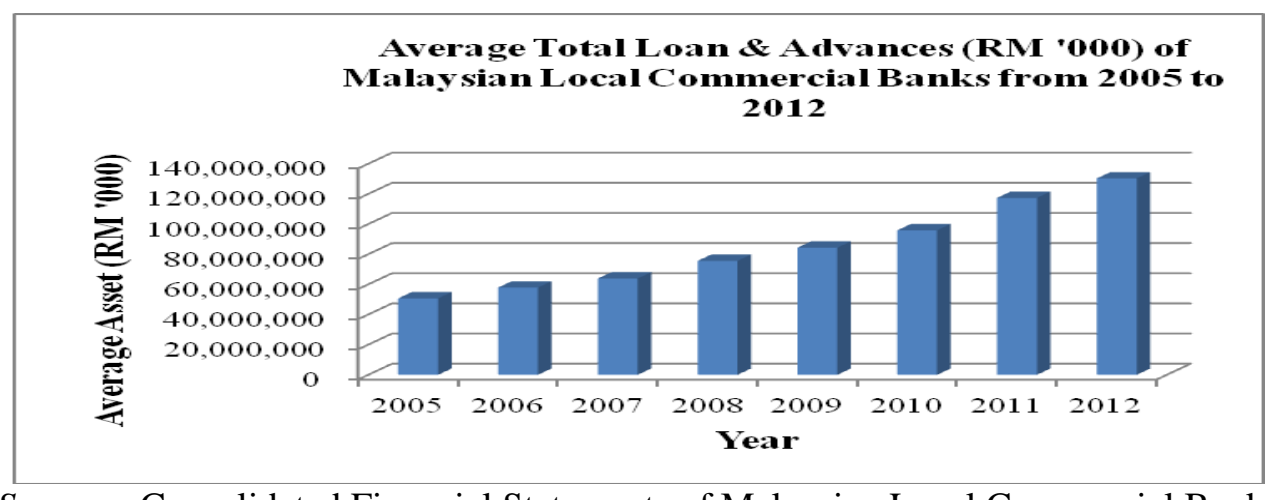

Sources: Consolidated Financial Statements of Malaysian Local Commercial Banks

\section{DATA AND METHODOLOGY}

\section{Data}

This study involved eight commercial banks incorporated in Malaysia which are Maybank, Public Bank, Hong Leong Bank, CIMB Bank, Affin Bank, Alliance Bank, AmBank and RHB. The data used in this study consists of the yearly data of return on asset (ROA), non-performing loan over total loan ratio (NPL/LA), total loan to total deposit ratio (LA/TD) and loan loss provision over total loan (LLP/LA) of all the Malaysian local commercial banks. The return on asset (ROA) used to measure the profitability of the commercial banks, while the NPL/LA, LA/TD and LLP/LA are used as the proxy of the credit risk. The data for this study are obtained from the respective banks' annual reports for the periods between 2005 and 2012. The annual reports was downloaded from the Bursa Malaysia official website. In order to compare the credit risk and profitability performance, the sample period was also divided into two-sub period, which is prior to the mortgage crisis period (2005-2008) and post mortgage crisis period (20092012).

\section{Methodology}

Using both pooled OLS and panel data estimation, we examine the relationship of the variable of interest deploying the following regression model: 


$$
\mathrm{Y}=\alpha+\beta_{1} \mathrm{X}_{1}+\beta_{2} \mathrm{X}_{2}+\beta_{3} \mathrm{X}_{3}+\beta_{4} \mathrm{DV}+\varepsilon
$$

$\mathrm{Y}=$ Return On Asset (ROA)

$\mathrm{X}_{1}=$ Non-Performing Loan / Total Loan \& Advances (NPL/LA)

$\mathrm{X}_{2}=$ Total Loan \& Advances / Total Deposit (LA/TD)

$\mathrm{X}_{3}=$ Loan loss provision / Total Loan \& Advances (LLP/LA)

$\mathrm{DV}=$ Dummy variable (Mortgage crisis)

$\mu=$ Error term

\section{EMPIRICAL FINDINGS}

\section{Descriptive Statistics}

Table 1: Results of Descriptive Statistics

\begin{tabular}{lllll}
\hline \multicolumn{1}{c}{ Variables } & \multicolumn{1}{c}{ Mean } & Standard Deviation & Minimum & Maximum \\
\hline ROA & 0.98 & 0.3954 & -0.85 & 1.59 \\
NPL/LA & 3.75 & 3.0605 & 0.69 & 14.23 \\
LA/TD & 76.05 & 9.9437 & 50.86 & 93.76 \\
LLP/LA & 0.69 & 0.6858 & -0.37 & 4.10 \\
\hline
\end{tabular}

Notes: All the variables measured in percentage

The average ROA of the Malaysian local commercial banks is $0.98 \%$ with standard deviation at $0.40 \%$ for the period between 2005 and 2012. The highest ROA recorded is at $1.59 \%$ and the minimum is at $-0.85 \%$. The average NPL/LA of all the banks is at $3.75 \%$. This indicates that on average $3.75 \%$ of the total loan defaulted by the borrowers. Throughout the study periods, the largest proportion of nonperforming loan percentage of total loan is at $14.23 \%$ and the lowest at only $0.69 \%$. In terms of LA/TD, Malaysian local commercial banks used on average $76.05 \%$ of the deposit to give out as loans to its customers. The maximum proportion recorded is at $93.76 \%$. On average, local commercial banks also set aside only $0.69 \%$ of the total loan as an allowance for bad loans.

\section{Regression Results}

The results of the Pooled OLS and Panel estimation are described in Table 2. For the Panel data estimation, the Hausman test suggests using a random effect model. The results indicated that only LLP/LA was negatively significant in influencing the bank's profitability in both models. LA/TD was found to be positively significant in Pooled OLS estimation but not in the Panel estimation. The NPL/LA has a negative relationship with profitability in both models although this is not significant. Although the coefficient is not significant, to some extent events such as the mortgage crisis, bank profitability was negatively affected by the crisis in both models.

The negative relationship found in between the non-performing loan to total loan ratio and ROA is consistent with the findings of recent studies by Kolapo et al. (2012), Nawaz (2012), Poudel (2012), Ogboi and Unuafe (2013) and Abbas et al. (2014). Nevertheless, findings from recent studies, Boahene et al. (2012) and Abiola and Olausi (2014) show that higher non-performing loan to total loan ratio (NPL/LA) tend to increases the profitability of banks.

Boahene et al (2012) argued that with the presence of high credit risk justifies banks charging extremely high lending interest rates as a result leading to high profitability. This trend was supported based on a report published in the Ghana Banking Survey Report (2010) by Pricewaterhouse Cooper. The 
report stated that the profitability of Ghana's banks on the non performing loan increased from GHS\$60 million in 2007 to GHS\$266 million in 2009, meanwhile the total income of the banking industry indicated a drastic increased from GHS\$798 million in 2007 to GHS\$1.5 billion in 2009. Even more intriguing, Abiola and Olausi (2014) noted that commercial banks with a weak credit risk management charged higher interest rate on the loan to offset the cost on loan default.

Table 2: Pooled OLS and Random Effect Model (Dependent Variable: ROA)

\begin{tabular}{lcccc}
\hline Variable & \multicolumn{2}{c}{ Pooled OLS } & \multicolumn{2}{c}{ Panel Model } \\
& Coefficient & P-value & Coefficient & P-value \\
\hline NPL/LA & -0.0150 & 0.313 & -0.0028 & 0.830 \\
LA/TD & $0.0074^{* *}$ & 0.030 & 0.0034 & 0.460 \\
LLP/LA & $-0.4459^{* * *}$ & 0.000 & $-0.4543^{* * *}$ & 0.000 \\
DV & -0.0480 & 0.865 & -0.0394 & 0.558 \\
C & 0.7960 & 0.003 & 1.0629 & 0.002 \\
R-squared & \multicolumn{2}{c}{0.6448} & \multicolumn{2}{c}{0.6321} \\
Hausman Test & & \multicolumn{3}{c}{$3.28(0.5126)$} \\
\hline
\end{tabular}

Major portion of banks operations primarily involves borrowing and lending activities. Thus, banks faced with high credit risk therefore they create loan loss provisions to mitigate this risk (Ali, Akhtar, \& Ahmed, 2011). Both models show that the loan loss provision to total loan has a significant negative relationship with the profitability of the Malaysian local commercial banks. This result corresponds with findings in studies by Ali et al (2011), Athanasoglou, Brissmis, and Delis (2008), Davydenko (2010), Mustafa, Ansari and Younis (2012), Kolapo et al (2012) and Riaz (2013). The weak credit risk policy of banks reflects on the bank's low profitability, because the loan loss provisions are created from retained earnings of banks on annual basis (Ali et al, 2011). However, this finding is at variance with the findings of Ogboi and Unuafe (2013); Sufian and Noor (2012); and Syafri (2012) where the higher the provision for the loan loss, the higher the profitability of the banks. Sufian and Noor (2012) argued that banks could reduce the variability of reported income by making higher provisions than necessary when credit quality and net income are high.

\section{CONCLUSION}

This paper examines the relationship between credit risk and commercial banks' profitability in Malaysia. Eight local commercial banks data spanning from 2005-2012 and both Pooled OLS and Panel estimation are used in this study. From this study it can be concluded that commercial banks in Malaysia has strong banking fundamentals. Based on the results, credit risk (NPL/LA and LLP/LA) has negative relationship with profitability. Commercial banks in Malaysia have good credit risk policy that contributes to higher profitability. Khoon and Lim (2010) noted that the Malaysian local commercial banks have strengthened and created significant buffers during the decade after the Asian Financial Crisis. Thus, Malaysian local commercial banks always reduce the loan loss provision and non-performing loan to total loan ratio (NPL/LA) especially after the recent mortgage crisis period. In addition, the impact of the mortgage crisis on Malaysian banking system was relatively modest due to the negligible exposure to US subprime loan products. In assessing financial system stability and resiliency Beatty and Liao (2009) reiterated the importance of loan-loss provisioning policy, because it is a key contributor for fluctuations in banks' profitability and capital positions, which has a crucial bearing on banks' supply of credit to the economy. 


\section{REFERENCES}

Abbas, A., Zaidi, S. A. H., Ahmad, W., \& Ashraf, R. U. (2014). Credit risk exposure and performance of banking sector of Pakistan. Journal of Basic and Applied Scientific Research, 4(3), 240-245.

Abiola, I., \& Olausi, A. S. (2014). The impact of credit risk management on the commercial banks performance in Nigeria. International Journal of Management and Sustainability, 3(5), 295-306.

Aduda, J., Gitonga, J. (2011). The relationship between credit risk management and profitability among the commercial banks in Kenya. Journal of Modern Accounting and Auditing, 7(9), 934-946.

Ali, K., Akhtar, M. F., \& Ahmed, H. Z. (2011). Bank-Specific and Macroeconomic Indicators of Profitability - Empirical Evidence from the Commercial Banks of Pakistan. International Journal of Business and Social Science, 2(6), 235-242.

Athanasoglou, P. P., Brissimis, S. N., \& Delis, M. D. (2008). Bank-specific, industry-specific and macroeconomic determinants of bank profitability. Journal of International Financial Markets, Institutions and Money, 18(2), 121-136.

Beatty, A., \& Liao, W. Y. S. (2009). Regulatory capital ratios, loan loss provisioning and pro-cyclicality. Loan Loss Provisioning and Pro-Cyclicality (August 26, 2009).

Berríos, M. R. (2013). The relationship between bank credit risk and profitability and liquidity. The International Journal of Business and Finance Research, 7(3), 105-118.

Boahene, S. H., Dasah, J., \& Agyei, S. K. (2012). Credit risk and profitability of selected banks in Ghana. Research Journal of Finance and Accounting, 3(7), 6-14.

Çerci, G., Kandir, S, Y., \& Önal, Y, B. (1997). Profitabililty analysis of banks: An application on the Turkish banking industry. The ISE Review Volume, 13(50), 30-44.

Chen, K. \& Pan, C. (2012). An Empirical Study of Credit Risk Efficiency of Banking Industry in Taiwan, Web Journal of Chinese Management Review, 15(1), 1-16.

Davydenko, A. (2010). Determinant of bank profitability in Ukraine. Undergraduate Economic Review, $7(1), 1-28$.

Demirguc-Kunt, A., \& Huizinga, H. (1998). Determinants of commercial bank interest margins and profitability: some international evidence. World Bank Economic Review, 13, 379-408.

Khoon, G. S., \& Lim, M. (2010). The impact of the global financial crisis: the case of Malaysia. Third World network (TWN).

Kolapo, T. F., Ayeni, R. Kolade., \& Oke, M. O. (2012). Credit risk and commercial bank's performance in Nigeria: A panel model approach. Australian Journal of Business and Management Research, 2(2), 31-38.

Mustafa, A. R., Ansari, R. H., \& Younis, M. U. (2012). Does the loan loss provision affect the banking profitability in case of Pakistan. Asian Economic and Financial Review, 2(7), 772-783.

Nawaz, M., Munir, S., Siddiqui, S. A., Ahad, T., Asif, M., \& Ateeq, M. (2012). Credit risk and the performance of Nigerian banks. Interdisciplinary Journal of Contemporary Research in Business, 4(7), 49-63.

Ogboi, C., \& Unuafe, O. K. (2013). Impact of credit risk management and capital adequacy on the financial performance of commercial banks in Nigeria. Journal of Emerging Issues in Economics, Finance and Banking (JEIEFB), 2(3), 703-716.

Poudel, R. P. S. (2012). The impact of credit risk management on financial performance of commercial banks in Nepal. International Journal of Arts and Commerce, 1(5), 9-15.

Riaz, S. (2013). Profitability determinants of commercial banks in Pakistan. Paper presented at International Business and Social Sciences Research Conference, Dubai, UAE.

Sufian, F., \& Noor, M. A. N. M. (2012). Determinants of bank performance in a developing economy: Does bank origins matters? Global Business Review, 13(1), 1-23. 
Syafri. (2012). Factors Affecting Bank Profitability In Indonesia. Paper presented at the 2012 International Conference on Business and Management, Phuket, Thailand.

THE WORLD BANK (2014). Credit depth of information. Retrieved April 7, 2014, from http://data.worldbank.org/data-catalog/world-development-indicators

Corresponding Author: Norlina Kadri can be contacted at knorlina@unimas.my 